\title{
The Küme Mongen and the Reign of God
}

\author{
M. Soledad Del Villar \\ Boston College School of Theology and Ministry, (Brighton, MA)
}

\begin{abstract}
This paper attempts to offer a theological reflection that compares two concepts from two different religious traditions that deal with a similar concern: guiding humanity and the cosmos to flourishing and abundant life. On the one hand, I will consider the Küme Mongen that comes from the Mapuche people of Chile and Argentina. On the other hand, I will consider the concept of the reign of God, so central to the Gospels and re-articulated frequently in Christology, specifically, Latin-American liberation theology. First, I will explain the context from which Küme Mongen emerges and give an account of the central ideas of this concept. Second, I will give an account of the treatment of the reign of God in J.A. Pagola and J. Sobrino's Christology. Finally, I will explore the possible connections between the Mapuche vision of fruitful life and the Kingdom of God, opening possible paths for mutual learning and understanding between the Mapuche and the Christian religious traditions.
\end{abstract}

\section{Text}

This paper attempts to offer a theological reflection that compares two concepts from two different religious traditions that deal with a similar concern: guiding humanity and the cosmos to flourishing and abundant life. On the one hand, I will consider the Küme Mongen that comes from the Mapuche people of Chile and Argentina. On the other hand is the concept of the reign of God, so central to the Gospels and re-articulated frequently in Christology, specifically that of LatinAmerican liberation theology. In doing this theological exercise, I do not intend to "colonize" indigenous thinking by imposing on it a Christian worldview. Instead, I am trying to offer some theological reflections that can allow Christians to understand better the sufferings and hopes of indigenous peoples in general and the Mapuche people in particular. This reflection can allow us to connect with them in solidarity, dialogue, and mutual learning, taking their religious traditions seriously. I use the word "religion" explicitly because too frequently Christians and Western 


\section{DEL VILLAR: $K \ddot{U} M E M O N G E N$ AND THE REIGN OF GOD}

thinkers do not recognize that indigenous people have a religion at all. By using words such as "cosmovision" or "spirituality", consciously or not, we end up invisibilizing and placing as inferior what are religious traditions in their own right. ${ }^{1}$ The first step to a fruitful theological dialogue is to consider that indigenous people have a religion that has survived even after more than 500 years of Western domination, colonization, and attempts at total annihilation.

First, I will explore the socio-political context in which the Mapuche people live and struggle, from where the Küme Mongen is rearticulated today. Then I will offer a brief account of the multiple dimensions of the meaning of Küme Mongen that can also be understood as an expression of Buen Vivir. After that, I will give a brief account of the reign of God as understood in contemporary liberation theology. Finally, I will offer some reflections about the possible dialogue between both concepts, centering my thoughts on how to re-read the reign of God in the light of the Mapuche aspirations of liberation and abundant life expressed in Küme Mongen. This will allow us Christians from Latin America to decolonize our thinking, moving beyond an exclusively European and Western way of understanding our religious tradition. This is urgently necessary precisely because the Church has been so many times complicit in colonial and neo-colonial projects in the Americas. We need to overcome these religious mentalities and practices in order to gain a deeper understanding of the potential meanings of the reign of God and the liberating message of the Gospel. In doing that, it is impossible to ignore the perspective of those who have been oppressed, not only economically and politically, but also culturally and religiously.

\footnotetext{
${ }^{1}$ Manuel Hurtado, "Hacer teología en medio de los pueblos originarios," Yachay 34, No. 66 (2017): 66.
} 


\section{DEL VILLAR: $K \ddot{U M E ~ M O N G E N ~ A N D ~ T H E ~ R E I G N ~ O F ~ G O D ~}$}

\section{The Mapuche People Today and the Re-articulation of the Küme Mongen}

The Mapuche people is an indigenous group that is composed of approximately $1,300,000$ persons, representing $83 \%$ of all the indigenous population in Chile. Most Mapuche live in the Santiago Metropolitan Region, due to a trend of migration from the countryside to the cities motivated by poverty. The rest of them live mostly in the rural areas of the Araucanía Region, which is part of their original territory in the south of Chile. The Araucanía region is the poorest region of the country, with $29.2 \%$ of the population living under the national poverty line. ${ }^{2}$ Among the poor people of the Araucanía, most are Mapuche. ${ }^{3}$

The poverty and exclusion that the Mapuche people suffer has deep historical roots. ${ }^{4}$ Unconquered by the Spaniards, the Mapuche were able to maintain their independence until the end of the $19^{\text {th }}$ century. The Chilean and Argentinean Republics conquered their lands between 1884 and 1920 and gave them to members of the Chilean and Argentinean elites and to German and Italian immigrants, forcing the Mapuche to live in reservations on the mountain slopes and the less fertile lands. The conquest and redistribution of land was justified using racial arguments that depicted the Mapuche people as lazy barbarians, and the new colonizers as bearers of civilization and progress. ${ }^{5}$

${ }^{2}$ Ministerio de Desarrollo Social, Encuesta de Caracterización Socioeconómica Nacional (CASEN) 2015, http://observatorio.ministeriodesarrollosocial.gob.cl/casenmultidimensional/casen/docs/CASEN_2015_Resultados_pueblos indigenas.pdf

${ }^{3}$ This considering not only economic poverty, but also access to education, healthcare and possibilities for living out their own culture, as measured by the IDH (Índice de Desarrollo Humano). A complete account of the differences between Chilean and Mapuche population in the Araucanía can be found in Patricio Padilla, "Mediciones del desarrollo y cultura: Índice de Desarrollo Humano y población mapuche en Chile," Polis, 40, 2015: 24 - 26.

${ }^{4}$ The following paragraphs are a summary of the Mapuche history, whose main source is the book of the mapuche historian Fernando Pairicán, Malón: La rebelión del movimiento Mapuche, 1990 - 2013 (Santiago, Chile: Pehuén Editores, 2014), 19 - 65.

${ }^{5}$ A similar process happened in the same period of time in the Argentinean side of the Wallmapu, or former Mapuche territory, that also included the Patagonia. 


\section{DEL VILLAR: KÜME MONGEN AND THE REIGN OF GOD}

While different indigenous political organizations developed during the $20^{\text {th }}$ century, it was not until the Agrarian Reform of the governments of the Chilean presidents Eduardo Frei and Salvador Allende $(1966$ - 1973) that some of the lands were returned to the Mapuche communities. But this did not last long. The dictatorship of Augusto Pinochet put a decisive end to the Agrarian Reform. The military illegally recovered most of the land and gave it back to their previous owners, or sold it at very low prices to major stakeholders in the forest industry. Furthermore, the dictatorship made illegal communitarian ownership of the indigenous lands, dividing Mapuche territories into individual and private property lots. Many Mapuche, because of their poverty, were forced to sell their land to the new industry and move to the cities, searching for new means of survival.

The forestry industry has created enormous profits for its owners. But it has not created a significant amount of jobs or material prosperity for those who inhabit the region. At the same time it created a dramatic impoverishment of the ecological biodiversity. The diversity of the native forest has been replaced with monocultures. Species such as pine and eucalyptus, not native to Chile, were introduced. These species have eroded the land and consumed enormous amounts of water, drying and contaminating the region. This industry has become a threat to the region's ecology and to the subsistence agriculture that most of the Mapuche people still practice. ${ }^{6}$ The exploitation of their ancestral land by the forest industry is particularly offensive to the Mapuche, who define themselves as "the people of the land": "Mapu" means land and "Che" means people. As with many indigenous peoples, they consider their land sacred. In consequence, the exploitation of their land is not only a form of economic injustice but also a serious ecological, cultural and religious offense.

\footnotetext{
${ }^{6}$ An exhaustive documentary on the topic was created by Resumen Televisión dir., Plantar Pobreza: El negocio forestal en Chile, 2014, https://www.youtube.com/watch?v=A42dHCxuJ1w
} 


\section{DEL VILLAR: $K \ddot{U} M E M O N G E N$ AND THE REIGN OF GOD}

An important process of political and cultural re-articulation of the Mapuche people began in the 1990s. During that decade, the whole Latin American region was shaken by a new wave of indigenist movements that advanced a new political perspective. The main principle that shaped these diverse movements was the ideal of territorial autonomy and political self-determination. It is in this context of political and cultural re-articulation that the concept of Küme Mongen was retrieved from the Mapuche religious tradition and re-signified.

Küme Mongen can be defined "as the yearning for a life in harmony with all beings, with other men and women, with God and spiritual forces, with nature in its infinite manifestations and with oneself." It presupposes a relationship of respect to and balance with other human beings, nature and the Divine. Human beings are not the owners of nature and its goods. Rather, humanity must interact respectfully with them: "The Mapuche asks permission to the 'Ngen' [sacred spirits that inhabit nature], to sink the plow, to collect the fruits or to enter the sea in search of sustenance. They want to provide what is necessary to live well without accumulating or destroying." sense, the Küme Mongen is a concept that has been used to critique the capitalist economy and especially its latest neo-liberal manifestations that have plundered the territory in which the Mapuche are called to live.

The most direct translation of Küme Mongen is "Living well", in Spanish, Buen Vivir or Buen Convivir. It is analogous to the sumaj kawsay and the suma qamaña, of the Quecha and Aymara cultures of the Andes. These concepts are today part of the Constitutions of Bolivia and Ecuador, and politically they represent an effort to overcome the Western concepts of development

\footnotetext{
${ }^{7}$ Nicolás Rojas and David Soto, "Küme Mongen: El buen con-vivir mapuche como alternativa de desarrollo humano y sustentable", 1 (paper presented at III Congreso social: Ecología humana para un desarrollo sostenible e integral, Universidad Católica de Chile, Santiago, Chile, 2016). [Retrieved from http://www.academia.edu] All translations of quoted texts in Spanish are my own.

${ }^{8}$ Misión Mapuche de la Compañía de Jesús, "Küme Mongen: la propuesta espiritual del pueblo Mapuche," Revista Mensaje 619 (June, 2013): 41.
} 


\section{DEL VILLAR: KÜME MONGEN AND THE REIGN OF GOD}

and progress as the only path forward for Latin-American peoples. ${ }^{9}$ As any deeply religious concept, Buen Vivir has its political, economic and ethical implications. According to David Choquehuanca, the goal is to vivir bien, no mejor, that is to live well, not to live better. To live better "in front of our neighbor, it is necessary to exploit, competition takes place, and wealth is concentrated in a few hands. Living better is selfishness, disinterest for others, individualism." In contrast, to live well is to "complement and not compete, share and not take advantage of the neighbor, live in harmony with people and with nature." 10 Fernando Huanacuni affirms something similar: "We have to differentiate between living well and living better. Living better means winning at the expense of others, accumulating just to accumulate, acquiring power just to acquire power. However, to live well is to restore balance and sacred harmony to life."11

Finally, an essential dimension of Küme Mongen is the restoration of harmony and balance. The Mapuche conceive the world as characterized by its duality. However, in this duality opposite realities and values complement each other rather than conflict. The harmony and complementarity of opposites must be achieved and fostered by the entire community in their respective territory. This implies developing values such as reciprocity and respect, that are essential for living well. ${ }^{12}$ In that sense many of the Mapuche perceive the current exploitation of their land as a huge imbalance that has to be corrected. Harmony has to be restored. In consequence, restoration becomes utopia, that both retrieves their ancestral tradition and pushes them to a new present and future characterized by harmony and respect, opposed to all forms of exploitation.

\footnotetext{
${ }^{9}$ Eduardo Gudynas, “Buen Vivir: Today's tomorrow” in Development 54, 4 (2011): 441 - 447.

${ }^{10}$ David Choquehuanca, "Hacia la reconstrucción del Vivir Bien," Dialogo Indígena Misionero 67 (Nov 2010): 20.

${ }^{11}$ Fernando Huanacuni, "Todo está interconectado, interrelacionado e interdependiente," Dialogo Indígena Misionero 67 (Nov 2010): 31.

${ }^{12}$ Rojas and Soto, "Küme Mongen," 5.
} 


\section{DEL VILLAR: KÜME MONGEN AND THE REIGN OF GOD}

\section{The Reign of God in Contemporary Christology and Liberation Theology}

Giving a complete account of the topic of the reign of God in contemporary Christology or even in Liberation Theology would be impossible considering the range of this article. I will limit myself giving a brief account of relevant points raised by two theologians: José Antonio Pagola, who writes privileging a historical perspective on Jesus' life and ministry; and Jon Sobrino, who interprets Jesus from the perspective of the poor and the oppressed of Latin America.

According to Pagola, the reign of God was "the core of Jesus' preaching, his deepest conviction, and the passion that inspired all of his activity. Everything that he said and did was in the service of God's reign." ${ }^{13}$ For Jesus, the reign of God was an event, a moment of decisive divine intervention. At the same time, that intervention could be grasped in the here and now of history. In his ministry, Jesus was trying to convince the poor peasants of Galilee that "the coming of God to establish justice was not a terrible, spectacular intervention but a liberating force, humble yet effective, and that it was there in the midst of life, within reach of anyone who accepted it with faith." 14

The message of the kingdom is intrinsically connected to Jesus' deeds among the poor. Jesus proclaimed the salvation of God by healing people. His goals were "to heal, to dispel suffering, to restore life." 15 He dismissed the sick and the sinners saying to them "Go in peace." This peace was not understood only as an inner state. It was "integral health, complete well-being, happy life in their families and villages, a life full of God's blessings." It is the desire of an integral and fruitful life, summarized in the Hebrew word shalom that describes "a complete kind of

\footnotetext{
${ }^{13}$ José Antonio Pagola, Jesus, an historical approximation (Miami, FL: Convivium Press, 2015), 99.

${ }^{14}$ Pagola, Jesus, 105.

${ }^{15}$ Pagola, 109.
} 


\section{DEL VILLAR: KÜME MONGEN AND THE REIGN OF GOD}

happiness: the opposite of a life of indignity, misfortune, the torments and illness of poverty."16 The reign of God was then a reign of abundant life and deep peace. Moreover, the primary recipients of that peace were the poor, the most deprived and excluded people among the communities Jesus visited.

The reign of God was at hand, but in order to enter into it, people had to change their way of thinking and acting, letting God change them and live accordingly to God's will. ${ }^{17}$ This challenged the political and economic structures of Jesus' time because it challenges the reign of other sovereigns that were not God: the Roman Empire and the Jewish authorities who were complicit with that empire. Entering into God's reign "meant leaving the empire imposed by the chiefs of the nations and the powerful rich" in order to let God rule. ${ }^{18}$ Moreover, even if Jesus never proposed a concrete plan to change the political structures of his time. Still his message was very political: it invited people to enter into a form of relationship with God and with other people that demanded solidarity with the poor and rejection of unjust oppression and discrimination.

To Jon Sobrino, the essential dimension of Jesus' mission and faith was the kingdom of God. Jesus did not preach himself but the kingdom. This kingdom was never directly defined, Jesus does not tell us what the kingdom is but affirms that is it at hand. ${ }^{19}$ In light of the Old Testament, we can say that the kingdom of God has two essential connotations: first, the idea that God rules and acts in history, and second, that God's actions are directed to transform bad and unjust historical realities into good and just. ${ }^{20}$ It designates a utopia, an ideal future of plentiful life for peoples who are promised that conflicts will turn into reconciliation, war into peace, and

\footnotetext{
16 Pagola, 111.

17 Pagola, 113.

18 Pagola, 115.

19 Jon Sobrino, Christ the Liberator, (Maryknoll, NY: Orbis Books: 2001): 69.

${ }^{20}$ Sobrino, Christ, 71.
} 


\section{DEL VILLAR: KÜME MONGEN AND THE REIGN OF GOD}

injustice into justice, making life possible, so those who work the land may enjoy the fruits of the land, building houses and living in them. ${ }^{21}$ This utopia appears as a good news to the people precisely "in the midst and in opposition of oppression of the anti-kingdom."22 In that sense, the kingdom exposes the injustice of the political and economic structures that work against the life of the poor and calls for a radical change.

Jesus follows and situates himself in continuity with this tradition of hope for the oppressed in history. He appears as one who believes that it is possible to overcome suffering in history: "He belongs then, to the current of those who hope in history, in the midst of oppression, who again and again formulate a utopia, who believe that justice is possible." ${ }^{23}$ To him, the arrival of the kingdom is imminent and at hand. It is also purely God's initiative, a gratuitous gift that calls us to conversion. And it is a good news, especially to the poor and the oppressed, to whom the kingdom is primarily addressed. In that sense, we can affirm with Sobrino that God takes sides and is partial in favor of the poor. This is expressed in the concreteness of Jesus' practice among the poor. He multiplies the bread, heals the sick and expels demons, not to demonstrate his supernatural powers and divinity, but to make the kingdom of God present through signs and works that concretely save the life of the poor from the specific oppressions they are facing. ${ }^{24}$

Both Pagola and Sobrino stress the centrality of the reign of God to understand Jesus' life and message. They also both stress that the liberation proposed by Jesus was not only a spiritual one, but a liberation which was very concrete and rooted in a hope of well-being for particular human beings, an overcoming of suffering and injustice that necessarily critiques the political, economic and religious structures that allowed that sufferings in the first place.

\footnotetext{
21 Sobrino, 72.

22 Sobrino, 72.

${ }^{23}$ Sobrino, 75 .

24 Sobrino, 90.
} 


\section{DEL VILLAR: $K \ddot{U M E ~ M O N G E N ~ A N D ~ T H E ~ R E I G N ~ O F ~ G O D ~}$}

\section{Possibilities of dialogue between the Küme Mongen and the kingdom of God}

The Küme Mongen and the utopia of the kingdom of God share important points of convergence. Both concepts share images of an ideal state of dignified life for human beings that is based on harmony and deep peace among them and with the Divinity. Both propose a lifestyle that leads to a good life and that is based both in spiritual and material well-being of human communities. Also, they both envision human relationships where there is no exploitation or abuse of any kind. Moreover, because of this, they both end up being concepts that critique the status quo that is shaped by unjust relationships, oppression, poverty, and lack of peace within the human community. As Jesus criticized the Roman Empire in his time by subverting its language of power, so the Küme Mongen and Vivir Bien subvert today's languages of power, being highly critical of the ideals of development and progress that Western civilization has imposed on indigenous peoples and lands.

Yet Küme Mongen stresses the importance of nature and the environment in a way that departs from the anthropocentrism that has been so characteristic of Christianity. In the words of Fernando Huancani:

When we talk about living well, we are talking about a process of naturalization and not just humanization, because the process of humanization that the West has raised, continues to consider the human being as king of creation and other beings as objects. To live well means to enter into a naturalization process, to be considered part of nature, to know that everything that exists in nature has a life of its own and to know that everything is interconnected and interdependent. ${ }^{25}$

Human beings are not over and apart from nature, but just a part of a complex community of living beings that are called to flourish together.

\footnotetext{
${ }^{25}$ Huanacuni, "Todo está interconectado,” 30.
} 


\section{DEL VILLAR: KÜME MONGEN AND THE REIGN OF GOD}

The different indigenous traditions of the Americas coincide in calling all of us to restore the right relationship between human beings and nature. True spiritual and physical harmony cannot be achieved if nature is exploited and used as a disposable object. This invitation could offer a corrective to the exaggerated anthropocentrism that many times has prevailed in interpreting Christianity and the project of the reign of God in particular. It is precisely this reinterpretation that Pope Francis attempted in his encyclical Laudato $\mathrm{Si}^{26}$ While he does not refer directly to the reign of God, he gives a general interpretation of Scripture that highlights the importance of the entire creation in the plan of God. Human beings are not called to dominate, but to take care of what he calls our "common home." ${ }^{\text {27 }}$ Furthermore, he proposes the Jesus himself was in full harmony with nature and was able to see in its beauty the provident will of the Creator. ${ }^{28}$ Nature was not just the scenery where his ministry took place, but a place of relationship that allowed him to discern a God who is caring and provident.

Still, it is important to mention that even when there have been attempts to reinterpret Christian tradition and Jesus' life and message in light of environmental concerns, the reign of God remains practically untouched. This is significant because if as Christians we do not integrate a right relationship with nature as part of what the fullness of life should look like, neither will we integrate it in our daily lives. If nature is not part of our future, how can it be part of our present? The reign of God itself as a concept need not be anthropocentric. In fact, if we link it with biblical imagery, the reign of God can also be envisioned as "the new heavens and the new earth" of the books of Isaiah (Isa. 65:17) and Revelation (Rev. 21:1), including the whole of creation with humans as part of it. Furthermore, the metaphors that Jesus used to speak about the kingdom address

\footnotetext{
${ }^{26}$ Francis, Laudato Si: On care of our Common Home (Vatican City: Vatican Press, 2015).

${ }^{27}$ Francis, Laudato Si, $\S 36-100$.

${ }^{28}$ Francis, $\$ 98$.
} 


\section{DEL VILLAR: KÜME MONGEN AND THE REIGN OF GOD}

directly the mysterious strength of life that is visible on nature. Parables such as the growing seed (Mark 4:26-29) and the mustard seed (Mark 4:26-29; Matt. 13:31-32; Luke 13:18-19) can be interpreted not only as metaphors of another reality, but as explicit images that signal nature's flourishing as the manifestation of the kingdom in our world. Another move forward would be to include the Earth among the poor who are the primary recipients of the kingdom. This is what Leonardo Boff suggests when he affirms that the same logic that oppresses the poor is today oppressing the Earth and that the Earth itself is among the most vulnerable beings of creation that need care, protection, and liberation. ${ }^{29}$

Finally, while both concepts point to an ideal state of dignified life both for the human beings and for creation, the Küme Mongen does not share the eschatological projection that is central to the concept of the kingdom. In that sense, it is an ideal that is less directed to the future and more centered in the present, in the here and now of human life. Still, the current situation of exploitation that does not allow this form of living to flourish has turned the Küme Mongen into a kind of utopia that shares the "already-but-not-yet" of the reign of God. Furthermore, the Küme Mongen addresses quite directly some of the problems of our Westernized modes of living, offering an alternative ideal of life that can help all of us to move away from exploitation and consumerism into more harmonious lifestyles, that respect the earth and the poor. In that sense, I agree with the Bolivian theologian Roberto Tomichá, who argues that we Christians need to decolonize our minds in order "to critically reintegrate the human person with their largely community-cosmic ancestral wisdom and, at the same time, to return to the evangelical style of Jesus of Nazareth in the concrete announcement of the kingdom of God or, in indigenous terms, to the implementation

\footnotetext{
${ }^{29}$ Leonardo Boff, Cry of the Earth, Cry of the Poor (Maryknoll, NY: Orbis Books, 1997), 113.
} 


\section{DEL VILLAR: KÜME MONGEN AND THE REIGN OF GOD}

of the Buen Vivir." ${ }^{30}$ Even if the theological and philosophical background of Küme Mongen and kingdom of God are different (and those differences are to be respected and honored), the Mapuche and the other indigenous peoples can find allies in their Christians neighbors. And in Jesus they can find, not their Liberator but their peñi, a dear brother, and a friend, available to be with them in the fight for a just and reconciled world.

${ }^{30}$ Roberto Tomichá Charupá, "Interculturalidad y misión en Indoafroamérica. Algunas premisas” in Desafios de una Teología iberoamericana inculturada en tiempos de globalización, interculturalidad y exclusión social, ed. Luis Aranguren \& Felix Palazzi (Miami, FL: Convivium Press, 2017), 486. 


\section{DEL VILLAR: KÜME MONGEN AND THE REIGN OF GOD}

\section{Bibliography}

Boff, Leonardo. Cry of the Earth, Cry of the Poor. Maryknoll, NY: Orbis Books, 1997.

Bresciani, Carlos, Juan Fuenzalida, David Soto and Nicolás Rojas. Mitos Chilenos sobre el pueblo mapuche. Santiago, Chile: Ediciones Revista Mensaje, 2018.

Choquehuanca, David. "Hacia la reconstrucción del Vivir Bien.” Dialogo Indígena Misionero, no. 67 (Nov 2010): $20-28$.

Francis. Laudato Si: On Care of Our Common Home. Vatican City: Vatican Press, 2015.

Gebara, Ivone. Longing for Running Water: Ecofeminism and Liberation. Minneapolis, MN: Augsburg Fortress, 1999.

Gudynas, Eduardo. “Buen Vivir: Today's tomorrow.” Development 54, no. 4 (2011): 441 - 447

Huanacuni, Fernando. "Todo está interconectado, interrelacionado e interdependiente." Dialogo Indígena Misionero, no. 67 (Nov 2010): 29 - 32.

Hurtado, Manuel. "Hacer teología en medio de los pueblos originarios." Yachay 34, no. 66 (2017): $59-78$.

Misión Mapuche de la Compañía de Jesús. "Küme Mongen: la propuesta espiritual del pueblo Mapuche," Revista Mensaje 62, no. 619 (June, 2013): 40 - 41.

Padilla, Patricio. "Mediciones del desarrollo y cultura: Índice de Desarrollo Humano y población mapuche en Chile." Polis, no. 40, 2015: 1 - 26.

Pagola, José Antonio. Jesus: An Historical Approximation. Miami, FL: Convivium Press, 2015.

Pairicán, Fernando. Malón. La rebelión del movimiento Mapuche, 1990 - 2013. Santiago, Chile: Pehuén Editores: 2014.

Rojas, Nicolás and David Soto. "Küme Mongen: El buen con-vivir mapuche como alternative de desarrollo humano y sustentable." Presented at III Congreso social: Ecología humana para un desarrollo sostenible e integral, Universidad Católica de Chile, Santiago, Chile, 2016.

Sobrino, Jon. Christ the Liberator. Maryknoll, NY: Orbis Books, 2001.

Tamayo, Juan José. Teologías del Sur: El giro descolonizador. Madrid: Ed. Trotta, 2017.

Tomichá Charupá, Roberto. "Interculturalidad y misión en Indoafroamérica. Algunas premisas." In Desafios de una Teología iberoamericana inculturada en tiempos de globalización, 


\section{DEL VILLAR: KÜME MONGEN AND THE REIGN OF GOD}

interculturalidad y exclusión social, edited by Luis Aranguren \& Felix Palazzi, 464 - 480. Miami, FL: Convivium Press, 2017. 